\title{
“"Upon your entry into the world": Masculine Values and the Threshold of Adulthood among Landed Elites in England 1680-1800'.*
}

\begin{abstract}
'Though you may have stored your mind with variety of laudable accomplishments, you are yet to learn the last and most important of all lessons - the art of using them' ${ }^{1}$
\end{abstract}

In August 1692, Humphrey Prideaux, dean of Norwich, responded to his sister Anne Coffin's request for advice about her eldest son, John, who was nearing the end of his time at school. ${ }^{2}$ As befitted a former Oxford don, Prideaux suggested sending John to either of the English universities, despite having serious misgivings about their intellectual and moral standards, which were eventually rehearsed in print. ${ }^{3}$ His characteristically bluff advice to his anxious sister was clear:

whatever you doe keep him not at home, noe way can be soe ready to ruin a yong man as that. Reather teach him to know the world \& when fortified with good education \& good instruction \& of an age to be ventured abroad you have don your part, and permit the rest to God's gracious providence.

Prideaux's stress on the need for John to leave home illustrates an interesting tension inherent in elite masculinity in the 
'long' eighteenth century. The position of the landed gentry as the 'natural rulers' of the country depended on the formation of a male gender identity that stressed personal autonomy, independent judgement and self-command. In the words of a Norfolk clergyman, Patrick St. Clair, (paraphrasing Lord Shaftesbury), this was learning 'to govern ourselves, \& then to govern others' ${ }^{4}$ However, these qualities could only be acquired and practiced by 'knowing the world', that is, by exercising personal freedoms that could be abused, with dangerous consequences for the family's dynastic and financial security. The alternative was continued domestic dependence that stunted the development of 'proper' masculine autonomy and judgement. This article will illustrate how a number of predominantly West-country landowners negotiated this parental dilemma, during the final, fraught formative stage in their sons' passage to adulthood.

This exploration also has a larger historical objective. By concentrating on practices within elite masculinity, it seeks to assess how gender values were assimilated, enacted and reproduced within families in this period. In comparison with approaches taken by historians of the sixteenth, seventeenth and nineteenth centuries ${ }^{5}$ discussion of masculinity in the 'long' eighteenth century has tended to concentrate on typifying norms and discourses abstracted from conduct literature, about masculinity/effeminacy, or politeness/domesticity, or on gender values as expressed through the prosecutions and publications 
relating to 'deviant' sexualities. ${ }^{6}$ Much less attention has been paid to identifying private understandings of masculine norms embedded in family correspondence, or to assessing how these related to published advice, or how they were transmitted over several generations. This study's emphasis is on interpreting values that were 'routinized' within families, that is, those rendered unremarkable by everyday rehearsal and mentioned only in passing between correspondents. Viewed individually, these values are tantalizingly implicit, and provide only fragmentary insights into the larger, unspoken understandings about characteristics appropriate to the elite male gender role. Collectively, though, this research suggests that they offer an important route to establishing how these imagined cultural ideals were rendered tangible as they provided standards by which to assess and influence behaviour.

Existing studies of the gentry have often tended to depict this lifestage as a matter of parental control of wayward youth, rather than as one in which sons' autonomy and independence was regarded as a positive male virtue, as well as a parental obligation. Heal and Holmes note the longstanding parental concerns about the moral risks and expense of sons' entry 'into the world', via the universities, inns of court or the embryonic Grand Tour. ${ }^{7}$ They suggest that gentry children were often sent away to school, 
university or Europe as much to distance them from the household servants, as to acquire worldly polish. ${ }^{8}$ More positively, though, they show that some parents valued 'learning, or the wisdom that comes from knowledge, as a serious goal', while most regarded universities at least as social finishing schools and sources of future patronage relationships. ${ }^{9}$ Black illustrates the same range of concerns about the Grand Tour, in which the desire for wider practical social, cultural and linguistic experience was tempered by the obvious parental fears of debauchery and debt. ${ }^{10}$

Cannon's study of the eighteenth-century aristocracy takes a slightly different stance, emphasising the growing acceptance of public, rather than private, schooling as a preparation for 'the world' of public life. ${ }^{11}$ University was an extension of this notion, and Cannon takes issue with Stone's thesis of precipitate aristocratic withdrawal from Oxford and Cambridge in the period. ${ }^{12}$ Brauer's 1959 study of advice literature surrounding gentlemanly education noted the public-private schooling debate, but gave weight to the competing contemporary concept of 'the world' - that is, practical experience gained outside the precincts of formal education. ${ }^{13}$ Brauer argued that 'the gentleman's sphere of activity was still society', so knowledge of it was necessary for him to deal with persons of different ranks, to discern (and anticipate) an individual's 'ruling passion', and to identify and learn from virtuous companions. ${ }^{14}$ The obvious disadvantages were the dangers of wine, women and gambling, largely as a result of a son acquiring 
too much freedom while insufficiently experienced to exercise it appropriately. Brauer concludes that 'the world' was seen as containing 'more threats to the gentleman's virtue than any other factor in his upbringing'. ${ }^{15}$

Historians who have viewed gentility more as a value system rather than as a series of life experiences have tended to relate these concerns more explicitly to contemporary understandings of manly (and gentlemanly) virtues. Steven Shapin and Anna Bryson have noted how commentators associated gentlemanly status with personal fitness to exercise power, and (therefore) with individual moral superiority derived from truthfulness, self-restraint, and independence of judgement (and means). ${ }^{16}$ As Shapin has observed, 'the culture that testified to the gentleman's identity... laid particular stress upon the facts of his independence and integrity relative to individuals in other social categories' ${ }^{\prime 17}$ Such personal qualities had to be learned and perfected before such a social role could be performed effectively. These qualities were individual and moral, but also gendered - as the values appropriate to a (financially and politically) disinterested cohort of male rulers. The identification of such gender values as integral parts of a social status allows us to understand how parents might regard their sons' 'entry into the world' as a positive step towards the attainment of the full prerequisites of active elite masculinity, rather than merely as a necessary evil, or an impulse to be restrained. 
McCormack has recently articulated these gender aspects of gentlemanly status and power in some detail. ${ }^{18} \mathrm{He}$ describes a political discourse that privileged freedom from obligation, 'a broadly common culture of manly virtue and assertive individualism' that stretched from the uncorrupted independent gentleman in parliament, to the artisan groups defending their rights collectively. ${ }^{19}$ In this culture, independence, and its unfettered exercise, was regarded as a properly 'masculine' characteristic, while dependence was a trait 'laudable in females, but contemptible - and supposedly effeminate - in adult men' ${ }^{20}$ While a number of historians have associated this preference for individualist self-fashioning with an emergent, early nineteenthcentury middle class, masculine independence was undoubtedly integral to gentlemanly status in the seventeenth and eighteenth centuries, albeit without the anti-aristocratic ideological edge that it later acquired.$^{21}$ Among its gentlemanly adherents, it may have formed part of the justification for their self-image as the kingdom's natural rulers, those who were truly 'free of the society of England', and constrained only by their own consciences. ${ }^{22}$

Anthony Fletcher has emphasized the significance of different educational stages in developing the requisite male independence. Firstly, he notes the imperatives among elite families to expose their adolescent sons to public schooling, with its physical and emotional separation, and its often harsh disciplinary regimes, in order to prevent undue maternal dependence (and thus 
'effeminacy'). Sons were lifted 'from the home into the future male world of leisured authority or of respected skilled work... enforced by the coercion of the birch rod'. ${ }^{23}$ Secondly, subsequent entry to university acted as 'a crucible of gender indoctrination', in which the inculcation of classical tropes of virtue and authority took place within a more open environment in which adult social accomplishments (and vices) could be rehearsed..$^{24}$ Thirdly, and increasingly, the Grand Tour offered both total immersion in the ancient past and the European present, but also the accompanying sink-or-swim experience of the vicarious hardships and pleasures of continental travel. As such, 'the point of the Grand Tour was not simply becoming a gentleman but becoming a man'. ${ }^{25}$

However, as Pollock observed nearly two decades ago, while such men were 'made not born', these qualities were not cultivated equally among sons of the gentry, since 'heirs were to be educated to maintain an estate, whereas younger sons were to be educated to acquire one ${ }^{26}$ As is shown below, this role also placed the heir in the position of 'mediator between his parents and his siblings', which was good training for his eventual assumption of the 'headship of the household'. ${ }^{27}$

There is some evidence in existing historical interpretations that adolescent 'entry into the world' was not just a dangerous but also a necessary stage on the road to full, gentlemanly discretion, autonomy and authority, particularly for heirs - something that parents might foster, as well fear. As yet, however, we know little 
about how gentry families actually sought to navigate this important, if perilous passage of life, and how parents and children behaved in relation to these cultural understandings. Analysis of this allows us to determine where the balance of power lay in this process between parents and children, and how far the situation changed between the later seventeenth and early nineteenth centuries.

This study is based on family correspondence from seven families based in Norfolk, Dorset, Devon and Cornwall, in the period 16701800. The chronological coverage of these archives is by no means uniform. ${ }^{28}$ Among the 460 letters analysed, the largest individual collections were the Pine-Coffin and Weld archives, particularly 78 letters from Humphrey Prideaux, dean of Norwich, to his sister Anne Coffin, between 1685 and 1705, and 52 letters home from Edward and John Weld while being educated at the Jesuit school of St. Omer, between 1758 and 1769 .

This extensive correspondence contains a couple of possible interpretative traps. As Jeremy Black has observed, to some extent the sources are self-selecting. ${ }^{29}$ Family correspondence tends to favour the diligent and dull son over the dilatory and disgraceful one. As a consequence, relations between parents/seniors and children in the sample conformed to a 'patriarchal' template, in 
which youth and inexperience deferred formally to age and authority, and resistance (where it occurred) was never overt. ${ }^{30}$

There are also problems caused by the composition of these archives. Almost two-thirds of the surviving letters are from children to parents or seniors, or between seniors, rather than directly from parents to children. ${ }^{31}$ The chances of out-going parental letters being preserved were much lower, unless the returning child incorporated them within his or the family's papers. Therefore, it is more difficult to access parental advice or strictures than it is sons' responses to them. The main counterweights to this bias are Humphrey Prideaux's letters to his sister, which rehearse 'parental' perspectives, letters by Jesuit preceptors to Edward and Thomas Weld after their departure from St. Omer, and John Buxton's published correspondence with his son Robert. ${ }^{32}$

This study will evaluate three important aspects of the relationship between filial 'entry into the world' and parental expectations about appropriate 'masculine' development. Firstly, it will explore parental understandings of this dilemma, and illustrate how fears were counter-balanced by recognition of the importance of personal autonomy within practices of elite masculinity. Secondly, it will show how families mitigated the perils of filial independence, particularly by inculcating 'familial' values, and selecting appropriate role models (often siblings). Thirdly, it will examine sons' responses to these efforts, and whether hidden differences of opinion were concealed beneath outward conformity. 
In doing so, it will assess how far sons sought to rehearse shared family assumptions in order to demonstrate the acquisition of 'proper' standards of judgement, and whether there were intergenerational differences or significant changes over time in the masculine values considered appropriate by these families, or in the strategies employed to secure them.

III

Tensions between parental guidance or supervision and the development of manly autonomy were manifested first as gentry sons were removed to residential schools. At this stage, parents were often more concerned to combat emotional dependence, and ward off 'unmanly' displays of feeling, than to restrain heedless autonomy. A series of letters between Juliana-Mary Buxton and her son, John Jacob, illustrate these parental concerns. John was warned by his mother of the dangers of school life while he was still a young boy at Ealing. The careful choice of friends was 'of infinite consequence' because 'young people are often led into many scrapes and much mischief by making hasty friendships. ${ }^{\prime 33}$ John then proceeded to Harrow, where the return correspondence indicates his problems away from home. His mother began gently by wishing that he '...thought less of coming home...' and hoping that he would soon be 'happy there'. Although she insisted that she always wanted him to express 'the genuine sentiments of your 
heart,' the following month her admonitions were rather more explicit. $^{34}$

...I hope you will cheer up and not dwell so much on coming home... pray endeavour to settle to your lessons and try to banish home from your thoughts and resolve to be as happy as you can, for believe me my love there is a very great sin in pining after what we cannot have and refusing to enjoy what we have. ${ }^{35}$

John's protests continued, and provoked his mother finally to a more pointed response.

Your letter is too importunate about coming home. I will keep it and show it to you and I am sure you will blush. ${ }^{36}$

As Fletcher has emphasized, comments such as this appear to reflect the belief even among elite mothers that correct masculine development required a decisive break from the maternal influence. ${ }^{37}$ Such separation was part of 'an overall process of hardening, of teaching self-control and endurance'.$^{38}$ John's mother threatened him with shame, and suggested that this display of unmanly behaviour would, in time, inspire its own effeminate reaction. ${ }^{39}$ Clearly, while she anticipated her young son's distress in facing life outside the parental home, her admonitions emphasized 
the necessity (and finality) of the process and urged her son to engage with the experience, for the good of his own masculine development.

From this point in adolescence, the issue increasingly resolved itself into the familiar tension between liberty and constraint. Humphrey Prideaux articulated the parental perspective with the greatest force among these correspondents. He believed that virtuous, right-thinking parents could only set their sons on the correct moral path, but could not lead them along it. ${ }^{40}$ Responding to his sister's approving mention of a female friend who had attempted to prescribe her son's religious beliefs, he observed caustically 'your foolish Neighbour that will put force upon her son... will certainly ruin him... \& ...breed him up only to be a plague unto her all her life after ${ }^{\prime 4}$ He asserted that such intervention by parents was justified only 'as long as their children have not judgement for themselves'. Prideaux was thinking here more of the individual religious development rather than the behaviour appropriate to virtuous masculinity, but he emphasized that parental heavy-handedness would weaken filial autonomy and lead to disaster.

For him, the dangers of parental over-protection were equal and opposite to those of parental delinquency. He traced the roots of declining moral standards among university students to failures in the parental home. 
Formerly there was discipline in familys \& youth were bred up in virtue \& sobriety at home and came to the universitys innocent \& untainted and alsoe with principles of Religion imprinted on them... ${ }^{42}$

In those halcyon days (before 1640?), when youths had internalised moral codes before their arrival at Oxford or Cambridge, the relatively weak university regulations were sufficient to keep them in check.

But now yong men are bred up after such an irreligious ungodly \& rude manner at home in their fathers houses that although the universitys bear the blame of their after debaucherys, they fore the most part bring them with them...43

Yet, college life was still preferable to the temptations of London, where there was no cloister within which to shelter such vulnerable youths. Prideaux lambasted his brother Edmund, who 'out of dislike to the Universitys sends his son first to London, Neither of the universitys is yet soe bad but the worst of them is Heaven in respect of that'. ${ }^{44}$ 
Prideaux articulated the importance of the universities as a valuable staging-post in the development of masculine independence. University life helped to resolve the tension between parental control and masculine autonomy by providing a regulated environment distant from familial authority, but also one in which surveillance by seniors was still possible. College tutors were the essential intermediaries in this process. The pastoral and supervisory role of tutors grew in the two universities from the later sixteenth century, as tuition was reoriented around individualised programmes of study.$^{45}$ Conscientious tutors were therefore valuable to families as much for their functions in loco parentis as for their educational skills - functions they could exercise without overt association with parental opinion, but sometimes in collusion with it. Concerned parents, such as the Coffins, judged colleges primarily according to the vigour remaining in their processes of moral regulation (and their political allegiances), and sought tutors who would inspire and control their charges. In 1696, Richard Coffin's London bookseller and inveterate correspondent, Richard Lapthorne, wrote complacently that his son would go to Pembroke College, Oxford, because it was governed in person by the Bishop of Bristol. ${ }^{46}$ Lapthorne noted that Pembroke was 'one of the best for sobriety and order and I am very glad that it is my sons lot to bee there...'. Prideaux's advice to his brother-in-law, in selecting solidly Whig Wadham College, was in the same vein, 'the greatest regard is to be had to the Company 
which he keeps', but fortunately, 'in that College', the Fellows were 'a very good sett of men' ${ }^{47}$ Certainly, they compared well to those of (Tory) Exeter College, who Prideaux felt were noteworthy only for 'drinking \& duncery'.

Tutors were expected to correspond with parents and seniors about the student's progress. Humphrey Prideaux received one such letter from Samuel Burton concerning the arrival of Richard Coffin's grandson, Edward Pine, at Cambridge in $1693 .{ }^{48}$ Burton was 'very glad to find in him good principles and good morals', despite the fact that he was 'very ill qualified as to school-learning'. He assured Prideaux that he would give 'the best of my Endeavours to improve him in learning and good Morals'. Arthur Onslow's didactic autobiography emphasized how he had benefited from his tutor's 'more than ordinary pains with me', despite the deficiencies in his studies at Oxford between $1708-10 .{ }^{49}$ He remembered his tutor as 'a learned discreet and virtuous man', who had supported Onslow's own punctilious inclinations towards college discipline.

The advent of the Grand Tour, or some more limited travel in Europe, amplified the dangers and opportunities. Although Humphrey Prideaux was full of advice to his sister and brother-inlaw about their son's departure to France in 1699, his words were now less effective. Prideaux, a younger son destined for the church rather than European travel, had advised his sister to keep John Coffin at Oxford for another two years. ${ }^{50}$ A year later it was clear that John wanted to go abroad, and the family arranged for him to 
be attached to the Earl of Manchester's diplomatic mission in Paris. ${ }^{51}$ This pleased Humphrey, who thought John would benefit from exposure to French manners, whilst enjoying much needed diplomatic protection in his travels round France..$^{52}$ Once established in Paris, though, John Coffin reassured his perennially anxious mother that travelling in France was much safer than in England, and that Uncle Humphrey did not know what he was talking about, since he had never been abroad..$^{53}$ This reflected the changing balance of power between John and his seniors. They could advise, and (crucially) retain financial control, but he was no longer under the surveillance of college tutors or other intermediaries. Increasingly, his letters became ones of information rather than consultation - telling his mother what he had done, rather than asking her advice on what he should do.

This change was recognised by other contemporaries. George Bubb Dodington's characteristically sententious remark to Anne East that 'the government of a gentleman of eighteen, master of a large fortune, is not a province of the most profound tranquillity for a lady', was accompanied by the injunction to deflect him towards Italy and away from Paris, 'where he will see and hear things, at an improper time of life'.$^{54}$ By contrast, Dodington's advice to East's son was a mixture of didacticism and realism. In addition to the standard cautions against extravagance, gambling and affectation, and in favour of virtue, patriotism and service that replicated contemporary conduct literature, Dodington offered more 
pragmatic suggestions. Conversation with women, was necessary to 'polish a firm and noble mind', particularly with 'ladies much older than yourself', who (perhaps euphemistically) would be 'very charitably inclined to put a young traveller on the right road'. ${ }^{55}$ Dodington also suggested that taking a governor was money 'quite thrown away', because 'one is never so well received as without one' ${ }^{56}$ Similarly, despite East's youth, Dodington advised that his guardians 'ought to be nothing but names, to carry your intentions into execution' because he should know 'what is proper for you to do', but as yet 'maybe not how to conduct it'. This apparent confidence was at odds with Anne East's maternal concerns to Dodington that her son was still 'very young, certainly not capable of judging for himself yet'. ${ }^{57}$ Dodington may simply have been trying to please both parties, but his advice recognised that there were now few financial, moral or personal restraints that could be applied.

Other elite families utilized a longer, more rigorous supervisory regime. Catholic families, such as the Welds of Lulworth Castle in Dorset, entrusted their sons to Jesuit academies in France, such as St. Omer, and universities, such as Rheims. ${ }^{58}$ Here, sons were committed to the care and constant supervision of Jesuit preceptors, from the ages of 8 or 10 years through university and Grand Tour. ${ }^{59}$ These men acted as spiritual mentors, surrogate parents, and trusted informants about sons' behaviour, morals and educational progress. This provided an all-encompassing service 
for distant parents, as well as inculcating the church's teachings in a regime of monastic austerity.

As intermediaries, these preceptors chose their epistolary tone carefully, and changed it over time. In adding postscripts to the youthful letters of Edward and Thomas Weld to their father, Jesuits such as John Chamberlain of Watten, adopted a parental voice. In 1760, Chamberlain wrote to Edward Weld Sr. that 'M[aste]r Tommy', or 'our little Man', had recovered from measles. ${ }^{60}$ As boys reached maturity, they were no longer addressed with diminutives, meriting instead an adult 'Sir', but the tone often remained one of familiarity and quasi-parental concern. Jenison wrote playfully to Edward Weld Jr. in 1768 that he sought revenge for Weld's lack of correspondence by writing 'to you so often, even when I have nothing to say, that your Patience will at length be as much spent by my letters as mine is by y[ou]r silence' ${ }^{61}$

At other times, such letters were more overtly didactic. In the spring of 1760, as Edward Weld left St. Omer for Rheims, his tutor Edward Church offered a variety of advice about 'genteel carriage' ${ }^{62}$ These included the conventional injunctions against 'any shadow of affectation', and 'effuse laughter in company', which English people regarded as 'a mark of ill-breeding'. Instead, Weld should be 'chearful \& free, but not forward', asking sensible questions of his elders, rather than forcing them to listen to him. Church excused his unsolicited comments, as being motivated by 
'an unfeign'd regard for you'. A few weeks earlier, Church had mixed flattery with advice, admiring his 'manly behaviour', but recommending that he adopt 'a certain degree of the Gaiete Francoise, which sits admirably well in an Englishman \& renders him both companionable \& agreeable in conversation' ${ }^{63}$ At the same time, he warned him to preserve his love of learning, unlike 'the greater part of young Gentlemen'. By this means, Weld would 'be both an honour to an ancient \& worthy family \& a support to virtue \& religion'.

By contrast, in correspondence Weld's father remained affectionate, but less insistent, and (inevitably) less aware of his progress. Weld Sr. asked, variously, whether his sons had been confirmed, enjoined James to persevere with his studies, and advised the consumptive Edward Jr. against taking up the bassoon. ${ }^{64}$ Before Edward Jr.'s departure from St. Omer to Rheims, his father was less prescriptive than Church, advising him airily to 'study a little Philosophy Aritmetick Geography \& those sort of Accomplishments for a Gentleman, and to remain a couple of years' ${ }^{65}$ Jesuit preceptors allowed Weld to subcontract the detail of his sons' educational, moral and spiritual development, in an environment that was more remote from the parental home than residential public schools or universities in England. 
While these elite families recognised the trade-off between parental desires for continued supervision of youths and the development of an independent, active masculinity, they also sought to retain control by attempting to get their sons to internalise approved values that would guide their behaviour in the future. John Jacob Buxton's mother expressed these imperatives when she wrote to him during his early schooling '...remember my dearest John all the admonitions we gave you and do not let the number of boys and the bad examples of some of them make you forget them... ${ }^{\prime 66}$ This attempt to provide a moral template within which filial autonomy was practised took three forms. These were direct moral injunctions by parents or seniors about specific issues, reference to conduct texts as general guides to behaviour, and the identification of appropriate role models, often from within the immediate family, on whom sons might base their behaviour.

To some extent, parental injunctions were effective only when there was a degree of consensus between parents and children about acceptable subjects for advice. Some were clear, if slightly surprising. Both Richard Coffin and Robert Buxton wrote home for advice about whether or not to adopt mourning dress on the deaths of (respectively) Queen Mary in 1694 and George I in $1727 .{ }^{67}$ Clearly, this was an issue in which they saw themselves as representatives of the political position of their families in a public environment, and not merely as autonomous individuals. Both applied for guidance to their fathers, as family heads. John Coffin 
noted that at his school, 'I have been wondered [at] that I am not in mourning already', while Buxton responded to his son's letter from Cambridge with the advice that 'I would have you do as other gentlemen where you are'.

There were other situations when sons, particularly eldest sons, were reminded directly by parents of their dynastic function. Henrietta Fortescue told her son Thomas Dyke Acland to be on his best behaviour when he stayed in the household of his intended bride in 1803, although the detail of her advice undercut its plea for dignity and maturity.

... shew an example of steadiness, manliness \& c. no practical jokes - ...you must no longer consider yourself a lad - but Sir Thomas Acland the representative of your family... ${ }^{68}$

She also expressed her concern that his stay with his fiancée would prove altogether too congenial, 'a veil of fascinating ideas... paths of roses'. 'I on the other hand would lead you o'er thorns \& briers [and] strengthen your constitution'. While this hyperbole was slightly ironic, her advice emphasized that her son's new stage in life required him to leave behind the private, familial identity of irreverent practical joker and develop a more austere, adult male identity appropriate to his public social status.

Other direct parental (particularly paternal) advice was reserved for more significant moments, such as leaving home for 
university. Richard Coffin advised his son, 'in the first place bee carefull to serve God' and maintain his private devotions. ${ }^{69}$ Secondly, Coffin warned John to 'avoid a debaucht person as you would doe one infected with the plague', and to account to himself each week 'what you have profited by your studys'. John Buxton was less prescriptive, possibly because he lived only about a day's ride from Cambridge. In 1727 he observed that John would sometimes have to 'converse out of your own society \& always let the worth \& good charactre of the person justifie you'.$^{70}$ These general words were then followed by specific advice about one of John's school-fellows who had proclaimed unorthodox religious views, and how to avoid guilt by association. As befitted two committed bibliophiles, both fathers also offered considerable advice on reading matter at university. ${ }^{71}$

Alongside such specifics, parents cited particular conduct texts so as to provide an approved, but more general, template for behaviour. Richard Coffin referred John to the Whig Lord Delamere's recently printed Advice to his Children (1694). ${ }^{72}$ This emphasized the necessity of daily religious devotions, asserting that 'our preservation is purchased by a very small price, even by a few minutes in private devotion'.$^{73}$ In recommending this text, Richard Coffin highlighted Delamere's advice that when morning devotions were hurried 'the day following was not prosperous', whether for study, health or general good fortune. ${ }^{74}$ By contrast, in 1727, John Buxton mentioned a much older work, Francis Osborn's 
Advice to a Son, first published in 1655 , and one that may potentially have been employed by several generations of the family. ${ }^{75} \mathrm{He}$ acknowledged that its age meant that 'allowance must be made for the style', but assured his son that it was 'so good that I can give you no better than to read it through... good sense can never be out of fashion' ${ }^{76}$

While Osborn's breezy injunctions were broadly conventional, they were often pragmatic rather than earnestly pious in the style of Delamere. Osborn advised sons not to flatter their egos with too much music or poetry, but to dress very well, in order to gain 'acceptance where ever you come'.${ }^{77}$ Other more pungent warnings included the suggestion that 'hee that owns a Whore in a more peculiar sense, then in a common Jakes, descends from the dignity of Reason', and the lesson that he 'who travells Italy, handsome, young and beardlesse', should beware 'the Lust of Men, as [well as] the affections of women' ${ }^{78}$

Buxton's recommendation of this apparently outdated publication carries implications about the consumption and circulation of conduct literature that contrast with those of recent studies. In particular, Carter based part of his evidence for the emergence of new, 'polite' forms of masculinity in the eighteenth century on the publication of criticisms of Osborn's advice, noting that Jonathan Swift and Samuel Johnson disagreed with his recommendations to dress ostentatiously when among 'others of like fortune. ${ }^{79}$ Carter contrasts this reception with accorded to the 
work during the restoration period from readers such as Samuel Pepys, who eagerly devoured several editions of the book. The use of Osborn's advice in the Buxton family almost twenty years after Swift's critical article in the Spectator and seventy after the publication of the text suggests that there may have been familial systems of values that could cut across or even disregard broader social discourses, or 'fashion', as John Buxton put it. To some extent, this preference for tried-and-tested texts also complicates chronologies of normative change based upon the dates of publication of such works.

The influence of Osborn's pragmatic frankness is apparent in the Buxton correspondence. Apart from one conventional reflection on his daughters' 'lot' in dealing with 'household affairs', John Buxton's letters to his sometimes sickly son concentrated on local visits and progress with the design and construction of his new country house.$^{80}$ Most of his advice related to enhancing social status at University, rather than supporting gender identity. ${ }^{81}$ By recommending Osborn's matter-of-fact 'good sense', Buxton could direct his son towards advice on subjects that were taboo, or at least embarrassing, for fathers and sons to discuss directly.

Conduct literature could be frank and comprehensive, but parents also searched for more concrete examples from family members. Generally, praiseworthy examples were selected, but occasionally bad behaviour was emphasized, as a deterrent. Humphrey Prideaux, who was never afraid to criticise his family, 
made much of the serious failings of his brother Edmund's son Jack. As was shown above, Humphrey disapproved of his brother's decision to apprentice Jack in London, and derived grim satisfaction as his fears were realised. In October 1700, Humphrey reported to his sister that Jack had run away from his master and was 'quite ruin'd'. ${ }^{82}$ The following January, he blamed Jack's father, for 'putting of his money into his hands before he had discretion to manage it', contrary to Humphrey's advice. ${ }^{83}$ By March, he had learned that Jack had become 'a pray to rogues \& whores... one whore in Drury Lane got $£ 200$ out of him' ${ }^{84}$ Prideaux believed that 'his refuge must be either to go to sea or to the army', but feared he was now 'utterly lost in wickednesse'. This example was not lost on his nephew John, who had earlier reported from London that he had not seen Jack, 'but have heard many a story of him which will be his ruin...85

Usually, the examples chosen were more positive. Writing to her son Henry at school in Alkenaan, Holland in the turbulent year of 1793, Priscilla Woolcombe advised him to study and copy his elder brother William's 'exemplary behaviour and great good sense' (and political conservatism) ${ }^{86}$ After Henry's return to Plymouth, William proffered his advice in several verbose letters from university in Edinburgh. While he disclaimed the talent necessary to 'to correct the faults of others', he thought that Henry might 'feel more inclined to seek assistance from a distance' on some matters rather than from those he was 'immediately with' ${ }^{87}$ 
Although William's comments on Henry's handwriting, reading habits and learning were didactic and potentially patronizing, he admitted to his brother that 'they result from daily experience in my own person', and stressed that he wrote only for Henry's eyes. ${ }^{88}$ In this sense, while William could not resist the opportunity to instruct his brother, he realised that he did so as his sibling, not his senior, noting parenthetically 'I think I hear you exclaim, when will this long lecture end[?]'89 Yet, it is clear that William's advice was intended to further his brother's masculine independence, particularly that 'habit of thinking \& judging for yourself, without which a man on entering into life is in danger of having his opinions shaken by all the arts that Sophistry can employ'. ${ }^{90}$ For William (the student) this intellectual autonomy was related directly to the rightful path of male development, 'that firmness \& decision of character, which is productive of as much happiness to its possessor, as it is a source of admiration to others' ${ }^{91}$ His brother's response is not recorded, but William was certainly attempting to provide a role model, or normative standards, for his brother's development, as his mother had intended. The same approach was adopted in the Acland family, where the eldest son, Thomas, was required by his mother to deal with his refractory younger brother Charles. In 1803 Henrietta Fortescue remarked that she hoped Thomas had given 'Charles plenty of preaching' at their recent meeting, as the latter seemed to be 'quite destitute of feeling' ${ }^{92}$ 
Dynamics in other families were slightly different. The Weld archive contains sporadic correspondence between the brothers Edward and Thomas Weld. Here, the balance of power changed after the sudden death of their father in 1762 . This projected Edward, into the role of household head, aged 21, in addition to his status as elder brother. Thomas was nine years' younger than his brother, and his responses oscillated between candid fraternal remarks about his educational difficulties, and recognition of his dependent financial position. In 1766, he wrote from school in Bruges of his lack of progress in Latin syntax, before insisting to his brother that his infrequent letters were not 'thro any neglect or wont of affection for you'. ${ }^{93}$ Two years later, at university in Colmar, he reassured his brother that he was now 'very much Changed, with regard to Study \& Reading to what I was when in England with you'. ${ }^{94}$

Edward had been a more successful student, while Thomas' difficulties were compounded by the disruptions to his studies after the suppression of the Jesuits in France in $1762 .{ }^{95}$ Aware of his brother's educational accomplishments, Thomas was keen to comply with his 'good advice', reporting that did not want to become a man who was 'scarce able to talk of anything but the Weather' ${ }^{96}$ At the same time, he remained financially dependent on his brother, asking for example that he and his preceptor, John Jenison, be allowed to treat the four religious houses on his journey home through Bruges in 1769, in order to avoid appearing 'scrubby 
fellows' ${ }^{97}$ The same financial issues, expressed with more irritation, were present between the Coffin brothers, after the death of their father in 1699. Two years later, Richard Jr. reminded his mother that although he was obliged to his elder brother for acting as surety for his apprenticeship bond, 'it is no more than what any one else would do for his brother', and hardly worthy of John's claim to be 'the best of brothers' ${ }^{98}$

In these ways, older brothers could be invoked as role models, concrete examples of how to exercise masculine autonomy within recognised familial norms. Patterns of adult life expectancy in the period also ensured that many elder brothers (such as Edward Weld, or John Coffin) were required in their early twenties to adopt the new role of family head, alongside that of older brother. This required them not only to advise or inspire, but also to direct, with an eye to the dynastic concerns (and finances) of the family. Arthur Onslow had to shoulder the same burden becoming, 'the father of a large family', 'though not twenty years old' ${ }^{99}$ His mother died five years later, leaving to his care a younger brother and four unmarried sisters, of whom the former proved the 'greatest difficulty'. ${ }^{100}$ Onslow decided against apprenticing him to trade, because of their father's past business difficulties, and because he thought it 'below him' ${ }^{101}$ Government service was 'too precarious to be relied upon', so instead Onslow settled upon the army, a career that suited his brother's 'courage and firmness', and his 'very handsome and manly countenance'. ${ }^{102}$ He determined to 
buy him a commission in the best regiment he could afford, because this gave him

a rank that enabled him, as soon as he came into the world, to keep the best company and live with the best of his family... ever remember it in the disposal of your children, especially your sons, that nothing will sink a person so low as to be in a station that will make his relations ashamed to keep him company. ${ }^{103}$

By these means, he felt he had discharged his obligation as elder brother and household head, setting up his brother in a profession of which his rich relations would not feel ashamed.

Generally, in the sample families, sons and siblings proved tractable when such decisions were made on their behalf. Beyond Dean Prideaux's sour reflections on his nephew Jack, and Henrietta Fortescue's chidings of Thomas Dyke Acland, there are few examples in these archives of filial disobedience. Instead children and juniors tried to maintain, but also to stretch, the family consensus on behaviour or decisions out 'in the world', without creating an outright breach. They achieved this by a mixture of creative re-interpretation of parental guidance, selective 
obedience, and strategic foot-dragging or silence. In many respects, this resembles the behaviour of other subordinate groups in relation to the powerful, as articulated by James C. Scott in his notion of the 'hidden transcript', subversive evidence of the 'weapons of the weak' in such bi-polar distributions of authority. ${ }^{104}$

The best evidence of this 'hidden transcript', in which parental norms were stretched, rather than broken, comes in the correspondence surrounding John Coffin's visit to France in 1699. This involved a series of negotiations and unilateral steps that transformed a brief European visit into an adventurous Grand Tour. Significantly, in terms of the concerns of this research, the initiative for a foreign journey lay with his (often protective) mother. In June 1699, John wrote to her from Oxford that he was in agreement with her proposal that he visit Holland, possibly in the following spring. In the mean time, he was thinking of following his Uncle Humphrey's advice to enter one of the Inns of Court, 'if my Father approves of it', signing himself (as always) 'your most dutifull \& most obedient son'. ${ }^{105}$

Previously, he had proved himself so, apologizing abjectly for disobeying a parental command over some spending while still at school, 'I confes I have don verry foolish in acting Contry to your command... it being the first time ever I desired any such thing and shall be the last' ${ }^{106}$ The only hints of disagreement with his parents had been about spending to match his social peers, something that was of greater concern to him in fashionable Oxford than to them 
in rural north Devon. In April 1696, he had complained to his mother from Oxford that, 'noe man of my gown (as the times are now) can live jenteel on less than an hundred and fifty pounds yearly'. ${ }^{107}$ Significantly, though, his protests were intended to get his mother to 'intercede' on his behalf with his father, to whom he may not have expressed himself so strongly. Two years later, preparing to visit Humphrey Prideaux in Norwich, he objected to the groom proposed by his mother, wanting instead 'one who may appear, like other Gentlemen's Servants, I mean in a better livery then, as I remember our servants usually ware' ${ }^{108}$ His insistent tone may have been because he felt that the extra expense would be outweighed by his parents' interest in him, as their heir, appearing to greatest social advantage. It might also reflect growing maturity and experience in 'the world'.

Humphrey Prideaux preferred John's secondment to the English ambassadorial mission to Paris, ${ }^{109}$ rather than Anne Coffin's favoured tour of safely Protestant Holland, because there was more to learn in France about manners and politics. ${ }^{110}$ Humphrey was also reassured because John had written him 'soe sensible a letter about... his resolutions for the future \& his inclinations for the present that I think he may be ventured anywhere'. John seemed to have accepted and internalised the family's values about appropriate moral and gender conduct, and could be trusted with the necessary autonomy. A month later, Humphrey reiterated the same message to his sister, considering John safe against the 
dangers of Parisian women, 'however, let not your admonitions be wanteing'. ${ }^{111}$

By November, after a couple of months at Paris and Versailles, John wished to travel to southern France. His mother was against it, fearful of persecution of Protestants in France, and concerned about rising costs and his elderly father's declining health, but again Humphrey Prideaux interceded. Although he admitted that her original intention had been that John 'should goe noe further than Paris', he advised that she allow him to travel 'towards the Southern parts of France'. ${ }^{112}$ However, this support was partly strategic, to divert John from thoughts of Italy. He wrote, 'I have scarce ever known any yong Gentleman travel into that Country but have come back ruined by it', presumably in both financial and sexual terms. ${ }^{113}$ A compromise was reached, in which John confirmed that his tour of Southern France would be followed by the original journey to Holland, 'which my Uncle has proposed to $\mathrm{me}^{\prime}{ }^{114}$

John's journey south was cut short by his father's death in January $1700 .{ }^{115}$ This necessitated his return to England, and he remained in London until August, when he wrote to his mother reviving the journey to Holland. ${ }^{116}$ It is not clear whether John intended to stay long in Holland, but after arriving in September, his next letter came from Switzerland at the end of October, having travelled for six weeks down the Rhine. ${ }^{117}$ From there he went on to winter in Geneva, whose Protestant credentials would surely have 
met his mother's approval, even if there is no evidence that he undertook the journey with her permission. Having come this far, his intention was now to head south to Italy, despite his uncle's earlier disapproval.

Significantly, perhaps, he announced his plan in a letter to his sister Dorothy in January 1701, rather than to his mother. ${ }^{118}$ It is not clear whether this leg of his journey was undertaken with his mother's approval, or after discussions with the family in England. Since his father's death, John had exerted more control over the family estate, and was now a seasoned international traveller. In this sense, he could shrug off family disapproval more easily than in the years when a minor extravagance required an abject apology to his parents.

Even so, this deviation from the family's original plan (or his uncle's understanding of it) did not symbolise any deeper rebellion against familial norms. John upheld these in several ways. Writing to his mother on the eve of his return from France after his father's death, he recorded his fear of falling into debt as a result of his travels. 'I shall therefore be guilty of a very great madness if I continue my travels abroad whilst I run myself in debt at home'.119 John's travels also allowed him to articulate familial religious preferences. Humphrey Prideaux occasionally berated his sister for inclinations towards nonconformity, and her son was careful to describe Catholicism in disapproving terms, possibly to allay his mother's fears. ${ }^{120}$ Writing from Rome in May 1701, John 
commented that 'he that woud be well settled in the protestant religion, must come to Rome \& see the ridiculousness of this' ${ }^{\prime 21} \mathrm{He}$ aligned his own autonomous 'rationality' and Protestant convictions with those of his mother, and the family. Similarly, on his return to London after his father's death he reported to his mother that he had discharged his French servant, noting 'you woud not have been pleased... he being a Papist'. ${ }^{122}$

Despite its deviation from his original plans, this behaviour did not incur Humphrey Prideaux's wrath. In March 1701, he noted (in contrast to the disreputable Jack Prideaux) that John would return from his European travels with 'all manner of worthy improvements' to assume the place of 'the worthiest Gentleman' in his county. ${ }^{123}$ He had earlier chided his sister not to begrudge him the funds for his travels. ${ }^{124}$ This approval was echoed by John's younger brother Richard. As noted above, although Richard vented annoyance about his brother's financial control, on John's final return to England in September 1701 he commented that, 'he's certainly one of the finest Gentlemen in the west of England' ${ }^{125}$

\section{VII}

These case studies emphasize entry into 'the world' as a pivotal moment in the development of elite masculinity. While all the families examined here were acutely aware of the dangers that lurked between the departure from parental scrutiny and the 
adoption of adult responsibilities, all seemed to have regarded it as a necessary, even desirable, developmental stage. This was the case even for perennial pessimists like Humphrey Prideaux and Anne Coffin, as well as for those who exhibited less concern, such as John Buxton or Edward Weld.

Significantly, also, it seems to have been an imperative shared as much by mothers as by fathers. Even if the immediate emotional connection was weakened when boys left for school, there is no sense in this correspondence that the maternal influence over male development disappeared thereafter. Women, like Anne Coffin, Juliana-Mary Buxton or Henrietta Fortescue, remained involved in advocating and securing conformity to accepted values of masculine autonomy, virtue and authority even as their sons toured Europe. They had internalised these gender norms and were determined to project them onto their sons, in the same way that they tried to shape their daughters' behaviour to fit templates of feminine subordination. As such, the formation of male gender identity remained 'women's business' long after sons had left the supposedly 'domestic sphere' of the household.

In fact, the vagaries of the life-cycle meant that such parental roles were performed by a variety of family members. With her brother's constant advice, Anne Coffin seems to have exerted practical authority over her son, while her elderly husband may have been less involved. The same is true of Priscilla Woolcombe. Edward Weld Jr. and Arthur Onslow had to take on parental 
responsibilities after their parents' untimely deaths. Yet, while the person occupying the position of familial authority might vary, there were considerable continuities in the advice they offered, in contrast to the shifting meanings of the advice offered in conduct books.

This study has also identified continuities in the strategies employed by families to structure or to phase this shift to full autonomy. These ranged from the formal to the informal. The most formal were the use of mediating institutions, such as the Universities, the services of the Catholic Church, or systems of metropolitan apprenticeship and 'household' discipline. All were subject to decline in the 'long' eighteenth century. There was a marked decrease in gentry sons entering Oxford or Cambridge after the second quarter of the eighteenth century. The dissolution of the Jesuits in 1773 temporarily ended the system of preceptors for English Catholic youths. Formal apprenticeship, and its requirement for unpopular 'servile' status, declined rapidly among elite trades in eighteenth-century London. In this respect, by the end of the eighteenth century elite youths may have gained access to the freedoms of 'the world' earlier than their great-grandfathers had done - at, say, eighteen, rather than twenty-one or twenty-four. At the same time, the rise of the Grand Tour may have increased the extent of this freedom, or (at least) decreased the degree of parental surveillance. 
Yet, as Humphrey Prideaux lamented, these mediating institutions still depended upon the value systems of those who entered them. In this sense, informal methods of self-policing remained the most important strategy employed by families to avert the dangers that accompanied youthful autonomy. This depended on the inculcation and internalisation of values that it was hoped would then serve as guiding principles for the rest of life.

Interestingly, this correspondence devotes much more attention to emphasizing the importance of these values than it does to describing them. Most of the qualities picked out were illdefined and contingent: 'steadiness', 'firmness', 'sense', 'courage', or 'manliness'. Presumably, it was unnecessary to spell these out because both parties understood the hidden inflections of these words. If further clarification was required, families were more likely to point to the examples of sibling role models, or (occasionally) to conduct literature, rather than by hazarding their own definitions of these ideals. Overall, the study has revealed strong continuities in the values and concerns of the correspondents. The private nature of the sources allows a glimpse of familial cultures of masculinity rooted in the everyday experiences of young men at a pivotal moment in their lives.

This imprecision of language highlights two further features of this research. The first is the extent to which such an unarticulated system of values rested upon a series of shared 
assumptions about appropriate behaviour between parents or other seniors and children. Apart from John Prideaux's concern to maintain appearances as a fellow-commoner at Oxford, and the notable example of his wayward cousin Jack, there are few examples in these letters of generational contests, or even of significant reinterpretations of existing norms. Doubtless, this apparent consensus is partly to be explained by children trying to tell their parents what they thought they wanted to hear, or at least, by them attempting to stay within the family's recognised normative boundaries. ${ }^{126}$ This explains the concern exhibited by all these sons to be seen to be living within their allowances (and the lifestyles these implied), or John Coffin's conscious alignment with his mother's religious opinions. Among the relatively pliant (but not necessarily unrepresentative) correspondents in this sample, children seem to have measured their moral and gender attributes according to the scales employed by their parents. This may also explain why it is very difficult to identify notable changes over time, in the values expressed, or even in the problems anticipated.

However, there is some (slight) evidence that leaving home produced a normative, as well as a geographic, distance between children and their parents. Experience of, and in, 'the world' undoubtedly produced a greater assurance in responding to the prescriptive tendencies of seniors, and implied a greater independence of mind. As John Coffin demonstrated, while this autonomy could override immediate parental wishes, it did not 
necessarily run contrary to long-term parental expectations. The exercise of 'good sense' required that the child should decide on the best course of action (that is the one most congruent with agreed moral and gender norms) in the circumstances, not simply that he obey his parents in all things. The acquiescence shown by Humphrey Prideaux, Anne Coffin or George Bubb Dodington to such independence of mind and decision-making, suggests that it was tolerated, and even expected, by seniors as part of the final moves towards full adulthood. The development of the Grand Tour raised the stakes in this process, because it was a 'total' experience, and may have involved tacit recognition that moral compromises were likely. ${ }^{127}$ It provided a more complete, and abrupt, finishing process than the institutional mediation experienced by Richard Coffin or Humphrey Prideaux, but the financial and emotional investments that it necessitated emphasize its importance to parents and children alike. The successful transmission of these values was as vital for the survival, honour and authority of gentry families as the strict settlement system or prudential marriage.

The deepest impression left by this family correspondence is one of an only partially-articulated impulse towards masculine autonomy, a state that was sought as a means of self-expression by sons, and required (and sometimes enforced) by parents in order to produce socially acceptable offspring. This imperative seems to have overridden filial obedience, and parental caution, and to have 
overcome concerns about cost and corruption. It was an amalgam of moral, gender and social considerations. The exercise of male virtue required both independence, to ensure that it was a free choice, and also temptations against which to test it. Elite masculinity rested upon the virtues that were practised in this way, and the self-command that was acquired by their exercise. Such self-possession and moral authority was an integral component of the self-image of the social elite in eighteenth-century England, and a justification for their power. Youthful exposure to 'the world' seems therefore to have been regarded as essential for the cultural reproduction of the gentry in this period, providing a normative 'Spartan' ordeal in which individual qualms were subordinated to a more general social purpose.

University of Exeter 
* This research is based on a British Academy research project SG-46123, 'Practices of Politeness: changing norms of masculinity in landed society, 1660-1800'. This was a pilot for a larger 3-year AHRC research project AH/E007791/1 'Man’s Estate: Masculinity and Landed Gentility in England, c. 1660-c. 1918' currently being conducted by the authors and Dr. J. Jordan. The authors are very grateful to Dr. Jordan for reading and commenting on an earlier draft of this article, and for the comments of participants on a version of this article delivered at the European Social Science History conference in Lisbon, Feb. 2008.

${ }^{1}$ J. Andrews, An Analysis of the Principal Duties of Social Life: written in imitation of Rochefoucault: in a series of letters to a Young Gentleman on his entrance into the world (London, 1783), 6.

${ }^{2}$ Devon R.O. Pine-Coffin correspondence Z19/40/7 H. Prideaux to A. Coffin, 21 ${ }^{\text {st }}$ Aug. 1692.

3 'Articles for the Reformation of the two Universities' (c. 1715), in The Life of The Reverend Humphrey Prideaux DD, Dean of Norwich, with several tracts and letters of his upon various subjects never before published (London, 1748), 199-237.

${ }^{4}$ Norfolk R.O. WKC 6/24 401x Patrick St. Clair to William Windham of Felbrigg, 21 ${ }^{\text {st }}$ July 1729. ${ }^{5}$ Shepard's excellent study of discourses and practices of masculinity concentrates on the century before 1660. A. Shepard, Meanings of Manhood in Early Modern England (Oxford, 2003). Foyster's detailed study has similar chronological boundaries. E. Foyster, Manhood in Early Modern England: Honour, Sex and Marriage (Harlow, 1999); Tosh's standard work on practices of middle-class masculinity concentrates on the nineteenth century. J. Tosh, A Man's Place Masculinity and the Middle-Class Home in Victorian England (New Haven \& London, 1999). Pollock's important article on education and gender roles covers the period up to 1700. L. Pollock, “"Teach her to live under obedience”: the making of women in the upper ranks of early modern England', Continuity and Change, 4, 2 (1989), 231-58.

${ }^{6}$ For overviews of the recent historiography of masculinity in this period, see A. Shepard, 'From Anxious Patriarchs to Refined Gentlemen? Manhood in Britain, circa 1500-1700', Journal of British Studies, 44 (2005), 281-95; K. Harvey, 'The History of Masculinity, circa 1650-1800', op. cit., 296-311; J. Jordan, 'Her-Story Untold The Absence of Women's Agency in Constructing Concepts of Early Modern Manhood', Cultural and Social History, 4, 4 (2007), 
575-83. For masculinity and effeminacy, see M. Cohen, Fashioning Masculinity: National Identity and Language in the Eighteenth Century (London, 1996); P. Carter, 'Men about Town: Representations of Foppery and Masculinity in Early Eighteenth-Century Urban Society', in H. Baker \& E. Chalus (eds), Gender in Eighteenth-Century England. Roles, Representations and Responsibilities (London, 1997), 31-57; P. Carter, Men and the Emergence of Polite Society, Britain 1660-1800 (Harlow, 2001), 124-62; E. Brinks, Gothic Masculinity: Effeminacy and the Supernatural in English and German Romanticism, (London, 2003); T. A. King, The Gendering of Men, 1600-1750, (Madison, 2004); M. S. Dawson, Gentility and the Comic Theatre of Late Stuart London (Cambridge, 2005), 145-204; J. M. Kelly, 'Riots, Revelries, and Rumor: libertinism and Masculine Association in Enlightenment London', Journal of British Studies, 45, 4 (2006), 796-818.

For domesticity, see L. Davidoff \& C. Hall, Family Fortunes: Men and Women of the English Middle Class, 1780-1850 (London, 1987); M. R. Hunt, The Middling Sort: Commerce, Gender, and The Family in England, 1680-1780 (Berkeley, 1996), 101-24, 193-215; V. Nünning, 'From "Honour" to "Honest" The Invention of the (Superiority of the) Middling Ranks in EighteenthCentury England' Journal for the Study of British Cultures, 2 (1995), 19-41.

For politeness, see Carter, Polite Society, op. cit., 15-87; essays by Carter, Fletcher, Foyster and Langford in Transactions of the Royal Historical Society, $6^{\text {th }}$ ser., 12 (2002); D. Kuchta, The Three-Piece Suit and Modern Masculinity. England, 1550-1850 (Berkeley, 2002); R.B. Shoemaker, 'Taming the Duel: Masculinity, Honour and Ritual Violence in London, 16601800', Historical Journal, 45, 3 (2002), 525-45; M. Cohen, “"Manners” Make the Man: Politeness, Chivalry and the Construction of Masculinity, 1750-1830', Journal of British Studies, 44 (2005), 312-30.

For masculinity and sexualities, see, R. Trumbach, 'Sex, Gender, and Sexual Identity in Modern Culture: Male Sodomy and Female Prostitution in Enlightenment London', Journal of the History of Sexuality, 2 (1991), 186-203; R. Trumbach, Sex and the Gender Revolution. Volume 1: Heterosexuality and the Third Gender in Enlightenment London (Chicago, 1998); G. E. Haggerty, Men in Love. Masculinity and Sexuality in the Eighteenth Century (New York, 1999); T. Hitchcock \& M. Cohen (eds), English Masculinities, 1660-1800 (Harlow, 1999); D. 
Turner, Fashioning Adultery: Gender, Sex and Civility in England, 1660-1740 (Cambridge, 2002); K. Harvey, 'The Substance of Gender Difference: Change and Persistence in Eighteenth-Century Representations of the Body', Gender and History, 14, 2 (2002), 202-23; K. O’Donnell \& M. O’Rourke (eds), Love, Sex, Intimacy and Friendship between Men, 15501800 (Basingstoke, 2003).

${ }^{7}$ F. Heal \& C. Holmes, The Gentry in England and Wales 1500-1 700 (Basingstoke, 1994), 2634, 271-3, 274 .

${ }^{8}$ ibid, 248.

${ }^{9}$ Heal \& Holmes, op. cit., 265-9.

${ }^{10}$ J. Black, The British Abroad The Grand Tour in the Eighteenth Century (London, 1992), 287303.

${ }^{11}$ J. Cannon, Aristocratic Century. The Peerage of Eighteenth-Century England (Cambridge, 1984), 39-44.

12 ibid, 44-59.

${ }^{13}$ G. C. Brauer, The Education of a Gentleman Theories of Gentlemanly Education in England 1660-1775 (New York, 1959), 117.

14 ibid, 118, 121-5.

15 ibid, 127.

${ }^{16}$ S. Shapin, A Social History of Truth: Civility and Science in Seventeenth-Century England (Chicago \& London, 1994), 77-8; A. Bryson, From Courtesy to Civility: Changing Codes of Conduct in Early Modern England (Oxford, 1998), 132-4, 176-92. Shepard has observed the same emphases about virtue, self-government and wider manly authority in the sixteenth and early seventeenth centuries. Shepard, Manhood, op. cit., 70-89.

${ }^{17}$ Shapin, op. cit., 49.

${ }^{18}$ M. McCormack, The Independent Man Citizenship and Gender Politics in Georgian England (Manchester, 2005).

19 ibid, 13.

${ }^{20}$ ibid. 
${ }^{21}$ Historians such as Carter and Nünning have argued that this shift may have originated with the furore over Chesterfield's letters in 1774. See Carter, Polite Society, op. cit., 76-87; Nünning, op. cit., 29-34. Tosh has emphasized this as a defining social boundary within nineteenth-century understandings of masculinity. J. Tosh, 'Gentlemanly politeness and manly simplicity in Victorian England', Transactions of the Royal Historical Society, 12 (2002), 45572. However, others have seen moral autonomy and independent agency as characteristic of elite masculinity in the sixteenth and seventeenth centuries. See S. D. Amussen, 'Gender, family and the social order, 1560-1725', in A. J. Fletcher \& J. Stevenson (eds), Order and disorder in early modern England (Cambridge, 1985), 196-215; S. D. Amussen, "“The part of a Christian man": the cultural politics of manhood in early modern England', in S. D. Amussen \& M. A. Kishlansky (eds), Political culture and cultural politics in early modern England: essays presented to David Underdown (Manchester, 1995), 213-33.

${ }^{22}$ P. Laslett, The World We Have Lost (London, 1965), 27-8.

${ }^{23}$ A. Fletcher, Gender, Sex and Subordination in England 1500-1800 (New Haven \& London, 1995), 300.

${ }^{24}$ ibid, 314.

${ }^{25}$ ibid, 317. In this Fletcher follows M. Cohen, 'The Grand Tour: Constructing the English Gentleman in Eighteenth-Century France', History of Education, 21 (1992), 241-57.

${ }^{26}$ Pollock, op. cit., 248-9.

${ }^{27}$ ibid.

28 These were: Pine-Coffin family (Devon) 1670-1705; Welds (Dorset) 1750-75; Filliter (Dorset) 1759-1802; Hayne (Dorset) 1735-52; Woolcombe (Devon) 1780-1801; Acland (Devon) 1760-1820; Wyvell, Mayors \& Tremayne (Cornwall) 1770-1800. These were supplemented by reference to A. Mackley (ed.), 'John Buxton Norfolk Gentleman and Architect Letters to His Son 1719-20', Norfolk Record Society, LXIX (2005), for the first quarter of the eighteenth century, and Cambridge University Library (CUL), Buxton correspondence, Box 113, for the years around 1800 .

${ }^{29}$ Black, op. cit., 189-90. 
${ }^{30}$ See K. Thomas, 'Age and Authority in Early Modern England', Proceedings of the British Academy, 62 (1976), 205-48.

${ }^{31}$ That is 289/459 where both correspondents could be identified, or 63 per cent.

${ }^{32}$ For the Welds' education, see M. Whitehead, “'In the Sincerest Intentions of Studying”: The Educational Legacy of Thomas Weld (1750-1810), founder of Stonyhurst College', Recusant History, 26, 1 (2002), 169-93.

${ }^{33}$ Cambridge University Library (CUL), Buxton Correspondence, Box 113/33, J. M. Buxton to J. J. Buxton, 15 $5^{\text {th }}$ Nov. 1796.

${ }^{34}$ ibid, Box 113/38, J. M. Buxton to J. J. Buxton, 21 ${ }^{\text {st }}$ Mar. 1803.

${ }^{35}$ ibid, Box 113/45, J. M. Buxton to J. J. Buxton, 30 ${ }^{\text {th }}$ Apr. 1803.

${ }^{36}$ ibid, Box 113/46, J. M. Buxton to J. J. Buxton, $25^{\text {th }}$ May 1803.

${ }^{37}$ Fletcher, op. cit., 296-7.

${ }^{38}$ ibid, 303.

${ }^{39}$ The role of women in securing familial honour has been stressed by L. A. Pollock, 'Honor, Gender and Reconciliation in Elite Culture, 1570-1700', Journal of British Studies, 46 (2007), 3-29.

${ }^{40}$ Devon R.O. Pine-Coffin Correspondence Z19/40/7 H. Prideaux to A. Coffin, $21^{\text {st }}$ Aug. 1692.

${ }^{41}$ ibid.

${ }^{42}$ ibid.

${ }^{43}$ ibid.

${ }^{44}$ ibid.

${ }^{45} \mathrm{~J}$. Looney, 'Undergraduate education at early Stuart Cambridge', History of Education, 10, 1 (1981), 9-19; V. Morgan, A History of the University of Cambridge: Vol. 2: 1546-1750 (Cambridge, 2004), 314-42.

${ }^{46}$ R. J. Kerr \& I. Coffin Duncan (eds), The Portledge Papers being extracts from the letters of Richard Lapthorne, Gent., of Hatton Garden, London, to Richard Coffin, Esq., of Portledge, Bideford, Devon from December $10^{\text {th }} 1687$ - August $7^{\text {th }} 1697$ (London, 1927), 220.

${ }^{47}$ Devon R.O. Pine-Coffin Correspondence Z19/40/7, H. Prideaux to R. Coffin, $14^{\text {th }}$ Feb. 1696. As a fellow-commoner, John Coffin dined with the fellows and associated with them more than 
pensioner or sizar students.

48 ibid, Z19/40/6, S. Burton to H. Prideaux, 24 ${ }^{\text {th }}$ Feb. 1693.

${ }^{49}$ H.M.C. $14^{\text {th }}$ Rep. App. Pt. IX, 'MSS belong to the Earl of Onslow', autobiography of Arthur Onslow, late speaker of the House of Commons, written to his son George (c. 1760), 497.

${ }^{50}$ Devon R.O. Pine-Coffin Correspondence Z19/40/7, H. Prideaux to A. Coffin, 30 ${ }^{\text {th }}$ Jun. 1698.

${ }^{51}$ ibid, Z19/40/8a-b, J. Coffin to A. Coffin, $9^{\text {th }}$ Jun. 1699; Z19/40/7 H. Prideaux to A. Coffin, $9^{\text {th }}$ Jun. 1699.

${ }^{52}$ ibid, Z19/40/7, H. Prideaux to A. Coffin, $17^{\text {th }}$ July 1699.

${ }^{53}$ ibid, Z19/40/8a-b, J. Coffin to A. Coffin, 30 ${ }^{\text {th }}$ Nov. 1699.

${ }^{54}$ H.M.C. Var. Coll. VI, MSS of Miss M. Eyre Matcham (Dublin, 1909), G. Doddington to A. East, $14^{\text {th }}$ Dec. 1754,26 . Dodington seems widely to have been regarded as a buffoon by his political contemporaries, 'a slightly ridiculous larger-than-life character, blinkered, vain, and with little principle'. A. A. Hanham, 'George Bubb Dodington, (1690/1-1762)', Oxford DNB (Oxford, 2004).

${ }^{55}$ ibid, G. Doddington to Mr. East, 2 ${ }^{\text {nd }}$ Mar. 1755, 27.

${ }^{56}$ ibid, G. Doddington to Mr. East, $17^{\text {th }}$ July 1755, 28-9.

${ }^{57}$ ibid, A. East to G. Doddington, $5^{\text {th }}$ Sept. 1755, 30.

${ }^{58}$ Whitehead, 'Thomas Weld', 170-2.

${ }^{59}$ A. C. F. Beales, Education under Penalty: English Catholic education from the Reformation to the fall of James II, 1547-1689 (London, 1963), 64-71, 158-73.

${ }^{60}$ Dorset R.O. D/WLC/C30 J. Chamberlain to E. Weld Sr., 27th Nov. 1760.

${ }^{61} \mathrm{ibid}, \mathrm{D} / \mathrm{WLC} / \mathrm{C} 37 \mathrm{~J}$. Jenison to E. Weld Jr., 27 ${ }^{\text {th }}$ June 1768.

${ }^{62}$ ibid, D/WLC/C47 E. Church to E. Weld Jr., 16 ${ }^{\text {th }}$ May 1760.

${ }^{63}$ ibid, D/WLC/C47 E. Church to E. Weld Jr., $8^{\text {th }}$ Apr. 1760.

${ }^{64} \mathrm{ibid}, \mathrm{D} / \mathrm{WLC} / \mathrm{C} 40$ E. Weld Sr. to E. Weld Jr., 24 ${ }^{\text {th }}$ Sept. 1757, 27 ${ }^{\text {th }}$ Jan. 1758, and $7^{\text {th }}$ Jan. 1761.

${ }^{65} \mathrm{ibid,} \mathrm{D/WLC/C40} \mathrm{E.} \mathrm{Weld} \mathrm{Sr.} \mathrm{to} \mathrm{E.} \mathrm{Weld} \mathrm{Jr.,} \mathrm{27}{ }^{\text {th }}$ Jan. 1759.

${ }^{66}$ CUL, Buxton Correspondence, Box 113/33, J. M. Buxton to J. J. Buxton, $15^{\text {th }}$ Nov. 1796.

${ }^{67}$ Devon R.O. Pine-Coffin Correspondence Z19/40/8a-b, J. Coffin to R. Coffin Sr., n.d.; Mackley (ed.), op. cit., J. Buxton to R. Buxton, 19 ${ }^{\text {th }}$ Jun. 1727, 110. 
${ }^{68}$ Devon R.O. Acland Papers 1148M add 36/893, M. Fortescue to T. D. Acland, n. d. [1803].

${ }^{69}$ Devon R.O. Pine-Coffin Correspondence Z19/40/8a-b, R. Coffin to J. Coffin, n.d.

${ }^{70}$ Mackley (ed.), op. cit., J. Buxton to R. Buxton, 17th Jul. 1727, 113.

${ }^{71}$ ibid, 108-9, 113, 115-6, 122, 124, 126-32, 134; Devon R.O. Pine-Coffin Correspondence Z19/40/8a-b, J. Coffin to R. Coffin, [1696].

${ }^{72} \mathrm{H}$. Booth, The Works of the Right Honourable Henry, late L. Delamer and Earl of Warrington (London, 1694). For Delamere's politics, see C. Rose, England in the 1690s Revolution, Religion and War (Oxford, 1999), 71-2, 80-1. Coffin's London correspondent, Richard Lapthorne wrote repeatedly to him about 'providential' interventions against delinquents. See Kerr \& Coffin (eds), op. cit., 29, 32-3, 49, 82, 90, 93-4, 101-2, 119, 127, 128, 146-7, 165-6, 169, 173, 175-6, 183, 213, 235-6, 249, 251-2, 260, 264.

${ }^{73}$ Booth, Works, op. cit.

${ }^{74}$ Devon R.O. Pine-Coffin Correspondence Z19/40/8a-b, R. Coffin to J. Coffin, [1696].

${ }^{75}$ Mackley (ed.), op. cit., J. Buxton to R. Buxton, 15 ${ }^{\text {th }}$ Feb. 1728, 127.

${ }^{76}$ ibid, J. Buxton to R. Buxton, 18 ${ }^{\text {th }}$ Mar. 1728, 130.

${ }^{77}$ F. Osborn, Advice to a Son; or, Directions for your better Conduct through the various and most important Encounters of this Life (London, 1655), 17.

${ }^{78}$ ibid, 81, 85.

${ }^{79}$ ibid, 106-7, quoted in Carter, op. cit., 58.

${ }^{80}$ Mackley (ed.), op. cit., J. Buxton to R. Buxton, $8^{\text {th }}$ May 1728, 137.

${ }^{81}$ ibid, J. Buxton to R. Buxton, $2^{\text {nd }}$ Sept. 1729,152 \& R. Buxton to J. Buxton, $7^{\text {th }}$ Sept. 1729 , 154, about gift of venison and whether it should be consumed in the college hall or at a private party.

${ }^{82}$ Devon R.O. Pine-Coffin Correspondence Z19/40/7, H. Prideaux to A. Coffin, 14 ${ }^{\text {th }}$ Oct. 1700.

83 ibid, H. Prideaux to A. Coffin, 17 $7^{\text {th }}$ Jan. 1701.

${ }^{84}$ ibid, H. Prideaux to A. Coffin, $5^{\text {th }}$ Mar. 1701.

${ }^{85}$ ibid, Z19/40/8a-b, J. Coffin to A. Coffin, $2^{\text {nd }}$ Mar. 1700.

${ }^{86}$ Plymouth \& West Devon R.O. PWDRO 710/400, P. Woolcombe to H. Woolcombe, 1793.

${ }^{87}$ ibid, PWDRO 710/401, W. Woolcombe to H. Woolcombe, $17^{\text {th }}$ Nov. 1793. 
${ }^{88}$ ibid, PWDRO 710/405 W. Woolcombe to H. Woolcombe, $12^{\text {th }}$ Aug. 1794.

${ }^{89}$ ibid, PWDRO 710/401 W. Woolcombe to H. Woolcombe, $17^{\text {th }}$ Nov. 1793.

90 ibid, PWDRO 710/406 W. Woolcombe to H. Woolcombe, $28^{\text {th }}$ Oct. 1794.

${ }^{91}$ ibid.

${ }^{92}$ Devon R.O. Acland Papers 1148M Add 36/896 M. Fortescue to T. D. Acland, n. d. [1803].

${ }^{93}$ Dorset R.O. D/WLC/C37 T. Weld to E. Weld, $8^{\text {th }}$ Sept. 1766.

${ }_{94}$ ibid, D/WLC/C37 T. Weld to E. Weld, 30 ${ }^{\text {th }}$ Oct. 1768.

${ }^{95}$ Whitehead, op. cit., 172-81.

${ }^{96}$ Dorset R.O. D/WLC/C37 T. Weld to E. Weld, 30 ${ }^{\text {th }}$ Oct. 1768.

${ }^{97}$ ibid, D/WLC/C37 T. Weld to E. Weld, $9^{\text {th }}$ July 1769. He remained dependent on Edward until the latter's early death in 1775, see D/WLC/C37, T. Weld to E. Weld, $11^{\text {th }}$ Jun. 1774.

${ }^{98}$ Devon R.O. Pine-Coffin Correspondence Z19/40/8a-b, R. Coffin Jr. to A. Coffin, $4^{\text {th }}$ Oct. 1701.

${ }^{99}$ H.M.C. $14^{\text {th }}$ Rep. App. Pt. IX, 498.

100 ibid, 501.

101 ibid.

102 ibid.

103 ibid.

104 J. C. Scott, Domination and the Arts of Resistance: Hidden Transcripts (New Haven, 1990), 17-44. A thoughtful consideration of Scott's ideas in a historical context can be found in M. J. Braddick \& J. Walter, 'Introduction. Grids of power: order, hierarchy and subordination in early modern society', in Idem (eds), Negotiating Power in early modern society: order, hierarchy and subordination in Britain and Ireland (Cambridge, 2001), 1-42.

${ }^{105}$ Devon R.O. Pine-Coffin Correspondence Z19/40/8a-b, J. Coffin to A. Coffin, 9 ${ }^{\text {th }}$ Jun. 1699. ${ }^{106}$ ibid., J. Coffin to A. Coffin, n.d.

107 ibid, J. Coffin to A. Coffin, $18^{\text {th }}$ Apr. 1696.

108 ibid, J. Coffin to A. Coffin, 6 $6^{\text {th }}$ May 1698.

${ }^{109}$ ibid, J. Coffin to A. Coffin, 15 $5^{\text {th }}$ July 1699.

110 ibid, Z19/40/7, H. Prideaux to A. Coffin, $9^{\text {th }}$ Jun. 1699.

111 ibid, H. Prideaux to A. Coffin, 17 $7^{\text {th }}$ July 1699. 
112 ibid, H. Prideaux to A. Coffin, $17^{\text {th }}$ Nov. 1699.

${ }^{113}$ On $29^{\text {th }}$ Dec. 1699, Prideaux expressed such views more strongly in a letter to his friend John Ellis. Commenting on Ashe Windham as the prospective Whig parliamentary candidate for Norfolk, he wrote 'but having had an Italian education, is all over Italiz'd, that is, an Italian as to religion, I mean a downright atheist; an Italian in politics, that is a Commonwealths man; and an Italian I doubt in his morals, for he cannot be perswaded to marry', in E. M. Thompson (ed.), 'The letters of Humphrey Prideaux sometime dean of Norwich to John Ellis sometime under-secretary of state 1674-1722', Camden Society, n. s. xv (1875), 193. See below n. 127.

${ }^{114}$ ibid, Z19/40/8a-b, J. Coffin to A. Coffin, 28 ${ }^{\text {th }}$ Oct. 1699.

115 ibid, J. Coffin to A. Coffin, $12^{\text {th }}$ Feb. 1700.

${ }^{116}$ ibid, J. Coffin to A. Coffin, $3^{\text {rd }}$ Aug. 1700.

117 ibid, J. Coffin to A. Coffin, 21 $1^{\text {st }}$ Sept. 1700; ibid, J. Coffin to A. Coffin, 23 ${ }^{\text {rd }}$ Oct. 1700.

118 ibid, J. Coffin to D. Coffin, 24 $4^{\text {th }}$ Jan. 1701.

119 ibid, J. Coffin to A. Coffin, $12^{\text {th }}$ Feb. 1700.

120 ibid, Z19/40/7, H. Prideaux to A. Coffin, 23 ${ }^{\text {rd }}$ Feb. 1687.

${ }^{121}$ ibid, Z19/40/8a-b, J. Coffin to A. Coffin, 30 ${ }^{\text {th }}$ May 1701.

122 ibid, J. Coffin to A. Coffin, 22 ${ }^{\text {nd }}$ Feb. 1700.

123 ibid, Z19/40/7, H. Prideaux to A. Coffin, $5^{\text {th }}$ Mar. 1701.

124 ibid, H. Prideaux to A. Coffin, $17^{\text {th }}$ Nov. 1699.

125 ibid, Z19/40/8a-b, R. Coffin to A. Coffin, 27 ${ }^{\text {th }}$ Sep. 1701.

${ }^{126}$ The formation of such familial gender norms has been emphasized by Crawford, in the context of the influence of religious values within the Henry family. P. Crawford, 'Katherine and Philip Henry and their children: a case study in family ideology', Transactions of the Historic Society of Lancashire \& Cheshire, 134 (1984), 39-73.

${ }^{127}$ Despite Prideaux's earlier censures about Ashe Windham's 'Italian' morals (see above n. 112), in 1738 Patrick St. Clair, who had been Windham's tutor on his Italian tour in the 1690s, expressed surprise to his former pupil about a neighbour's remark that English gentlemen travelling overseas 'mind nothing but w[horin]g, drinking \& gaming', and hoped Windham's son William would be free from such vices while in Geneva. Norfolk R.O. WKC 6/24 401x Patrick St. 
Clair to William Windham of Felbrigg, $12^{\text {th }}$ Aug. 1738. 